\title{
Primary Atypical Lipomatous Tumor of the Orbit
}

\author{
Mahmood Dhahir Al-Mendalawi, MB, CH.B, DCH, FICMS \\ Department of Paediatrics, Al-Kindy College of Medicine, University of Baghdad, Baghdad, Iraq \\ ORCID: \\ Mahmood Dhahir Al-Mendalawi: https://orcid.org/0000-0003-2872-453X
}

J Ophthalmic Vis Res 2019; 14 (4): 536-536

Sir,

I read with interest the case report by Dworak et al on orbital atypical lipomatous tumor (ALT), a rare variety of liposarcoma, in an American patient. ${ }^{[1]}$ It is obvious that in addition to opportunistic infections, patients infected with human immunodeficiency virus (HIV) are also more susceptible to various types of tumors. The origin of these tumors is thought to be multifactorial, including immunosuppression, co-infection with oncogenic viruses, and life prolongation secondary to the use of antiretroviral therapy. ${ }^{[2]}$ Among these tumors, liposarcomas have been reported in HIV-positive patients. $^{[3,4]}$ To my knowledge, HIV infection is a distressing health threat in the United States of America (USA). According to the available data, an estimated 1.1 million people aged $\geq 13$ years were living with HIV infection in the USA at the end of 2015, including an estimated 162,500 (15\%) persons with undiagnosed infections. ${ }^{[5]}$ I presume that HIV infection ought to be considered in the patient studied in the aforementioned case. Hence, testing of HIV status using the diagnostic panel of CD4 count and viral overload measurements was solicited in the studied patient. If that diagnostic panel was conducted and disclosed HIV infection, the case in question could surely be considered

This is an open access journal, and articles are distributed under the terms of the Creative Commons Attribution-NonCommercial-ShareAlike 4.0 License, which allows others to remix, tweak, and build upon the work non-commercially, as long as appropriate credit is given and the new creations are licensed under the identical terms.

Correspondence to:

Mahmood Dhahir Al-Mendalawi, MB, CH.B, DCH, FICMS. Baghdad Post Office, Baghdad 55302, Iraq.

Email:mdalmendalawi@yahoo.com

Received: 01-12-2018

Accepted: 10-02-2019 novel as HIV-associated orbital ALT has never been reported in the literature so far.

\section{Financial Support and Sponsorship}

Nil.

\section{Conflicts of Interest}

There are no conflicts of interest.

\section{REFERENCES}

1. Dworak DP, Patel SA, Chennuri R, Falco D. Primary atypical lipomatous tumor of the orbit: A case report. J Ophthalmic Vis Res 2018;13:78-80.

2. Valencia Ortega ME. Malignancies and infection due to the human immunodeficiency virus. Are these emerging diseases? Rev Clin Esp 2018; 218:149-155.

3. Grieger TA, Carl M, Liebert HP, Cotelingam JD, Wagner KF. Mediastinal liposarcoma in a patient infected with the human immunodeficiency virus. Am J Med 1988;84:366.

4. Leonetti G, Forte A, Covotta A, Manfredelli S, Campo S, Bezzi M, et al. Cervico-thoracic liposarcoma in an HIV patient. G Chir 2008;29:427-428.

5. Dailey AF, Hoots BE, Hall HI, Song R, Hayes D, Fulton P, et al. Vital signs: Human Immunodeficiency Virus testing and diagnosis delays - United States. MMWR 2017;66:13001306.

\begin{tabular}{|l|}
\hline Access this article online \\
\hline Website: https://knepublishing.com/index.php/JOVR \\
\hline DOI: $10.18502 /$ jovr.v14i4.5479 \\
\hline
\end{tabular}

How to cite this article: Al-Mendalawi MD. Atypical Lipomatous Tumor of the Orbit. J Ophthalmic Vis Res 2019;14:536-536. 